\title{
Estimation of Sediment Yield of Govindsagar Catchment, Lalitpur District, (U.P.), India, Using Remote Sensing and GIS Techniques
}

\author{
Akram Javed ${ }^{1}$, K. Tanzeel ${ }^{1 *}$, Mohammad Aleem ${ }^{2}$ \\ ${ }^{1}$ Department of Geology, Aligarh Muslim University, Aligarh, India \\ ${ }^{2}$ Geological Survey of India, Hyderabad, India \\ Email: ^tanzeelsiddiqui@outlook.com
}

How to cite this paper: Javed, A., Tanzeel, K. and Aleem, M. (2016) Estimation of Sediment Yield of Govindsagar Catchment, Lalitpur District, (U.P.), India, Using Remote Sensing and GIS Techniques. Journal of Geographic Information System, 8, 595- 607. http://dx.doi.org/10.4236/jgis.2016.85049

Received: August 2, 2016

Accepted: October 28, 2016

Published: October 31, 2016

Copyright $\odot 2016$ by authors and Scientific Research Publishing Inc. This work is licensed under the Creative Commons Attribution International License (CC BY 4.0).

http://creativecommons.org/licenses/by/4.0/

\begin{abstract}
Soil erosion is a global phenomenon, which results in sedimentation and siltation of reservoirs of major rivers. Remote sensing data provide a synoptic view from which several surface parameters can be derived to assess the sedimentation yield in the reservoirs. Hence estimation of sediment yield has become one of the important tasks for planners, engineers and decision makers. The present study in Govindsagar catchment, Lalitpur District, Uttar Pradesh (India), has been carried out using IRS LISS III data to analyse land use/cover characteristics besides drainage basin characterstics. Subsequently, Sediment Yield Index (SYI) of Govindsagar catchment has been estimated using surface derivatives and morphometric parameters using empirical formulae. Integration of results obtained from satellite data and morphometric analysis suggests that the Govindsagar catchment has very low rate of sediment yield i.e. $0.07 \mathrm{ha} \cdot \mathrm{m} /$ year indicating a gentle slope and sustainable land use practices in the catchment. Low sediment yield also suggests less erosion in the catchment areas and healthy land use/cover scenario.
\end{abstract}

\section{Keywords}

Sediment Yield Index (SYI), Catchment, Remote Sensing, GIS, Land Use/Land Cover

\section{Introduction}

Soil erosion is universally recognized as a serious threat to human being [1]. It is a widespread problem threating the sustainability of agriculture productivity and causing deterioration of both land and water resources. The severity of this problem is more pronounced in arid and semi-arid regions especially on grazing land, where high rain- 
fall intensities of short duration, susceptibility of soil to erosion and human mismanagement of land have accelerated soil losses through erosion leading to downstream sedimentation. Catchments and watersheds have been identified as planning units for administrative purpose to conserve land and water resources [2]-[5]. The concept of watershed management recognizes the inter-relationships between land use, soil and water and the linkage between uplands and downstream areas [6]. Soil and water conservation are key issues in watershed management in India for demarcating the priority watersheds. The average soil loss rate has been computed as $16.75 \mathrm{t} \cdot \mathrm{ha}^{-1} \cdot \mathrm{year}^{-1}$ which translates into approximately $1 \mathrm{~mm}$ per year [4]. Besides degrading the land, erosion has direct bearing on the quantity and quality of water as well, since water carries with it loose soil that later gets deposited in the reservoirs and dams reducing both their storage capacity and life span. Compared to humid regions, the problem of soil and water erosion is altogether different in arid regions where flash floods are a common phenomenon [7]-[9]. Sediment yield from any area is a resultant of the interaction of meteorological factors with the land surface. Rainfall is the most important single meteorological factor that through in arid areas wind power assumes equal significance. The land factors include physiography, slope, soil, land use, vegetation and present status of erosion. Soil factors comprise the broad nature of the soil, effective depth, texture of the surfaces oil, soil reaction and stone content. It is the combined and reciprocal influence of these factors that determine the magnitude of the sediment yield from any locality.

Numerous attempts have been made to explain global and regional patterns of sediment yield in terms of climate and topography [10]-[15]. It has been estimated that in India about 113.3 million hectares of land are subjected to soil erosion due to water and about 5334 million tons of soil are being detached annually due to various reasons [16]. Since a host of variables are involved in erosion, it becomes difficult to measure or predict erosion accurately. The latest advances in remote sensing technology and geographical information sciences (GIS) provide real-time information on various aspects of the watershed such as land use, physiography, soil, relief, drainage characteristics, etc. It also assists in identification of existing or potential erosion-prone areas and provides data inputs to many of the soil erosion and runoff models. The rate of soil loss is judged by the Sediment Yield Index (SYI), which can be derived through various empirical formulae. In India, SYI model is developed by the All India Soil and Land Use Survey (AISLUS), and is commonly employed in providing criteria for priority delineation in river valley projects and flood-prone rivers. Several attempts have been made to estimate sediment yield in the recent past in various basins of India, using SYI and other conventional methods [17]-[23].

The present study makes an attempt to assess the sediment yield rate of the Govindsagar Catchment by using standard method with the aid of remote sensing data and drainage parameters.

\section{Study Area}

Govindsagar catchment falls in Lallitpur district which is the southernmost part of Ut- 
tar Pradesh (India) and lies between $24^{\circ} 24^{\prime} \mathrm{N}$ to $24^{\circ} 43^{\prime} \mathrm{N}$ latitude and $78^{\circ} 17^{\prime} \mathrm{E}$ to $78^{\circ} 28^{\prime} \mathrm{E}$ longitude, covering an area of about $384.35 \mathrm{Km}^{2}$ (Figure 1). The area falls in Survey of India (SOI) Toposheet numbers $54 \mathrm{~L} / 6$ and $54 \mathrm{~L} / 7$ on 1:50,000 scale. The maximum and minimum elevations in the catchment are $531 \mathrm{~m}$ and $336 \mathrm{~m}$ above mean sea level (amsl) respectively. The main Shahzad river and its tributaries form dendritic to sub dendritic drainage pattern, representing more or less gentle slope and plain topography. Geologically, the study area comprises of granites, gnisses, schist, sandstone, limestone, shale and alluvium. The soil in the catchment comprises of sand, silt, clay, red soil and laterites. Govindsagar reservoir is formed due to the dam constructed on

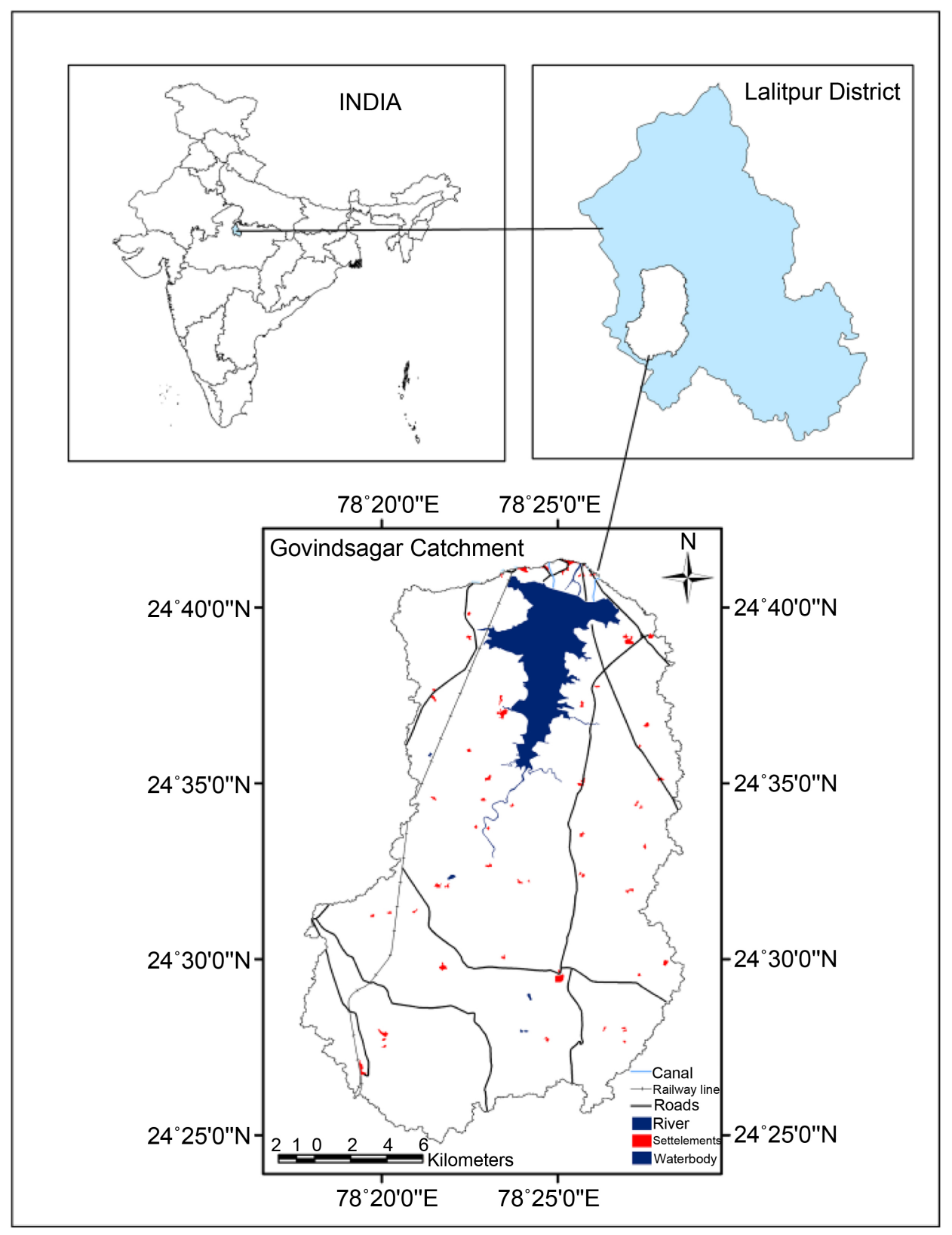

Figure 1. Location map of study area. 
Shahzad river near Lalitpur town. The catchment is predominated by agricultural land, however, forest cover is present in the southern part. The main crops grown are wheat, barley, maize, chana, mustard etc. which are irrigated through canals, tube wells and surface streams. Though the catchment receives average annual rainfall of more than $1044 \mathrm{~mm}$, but major part of the catchment faces acute shortage of water for drinking and irrigation purpose during summer. Socio-economically, this region known as "Bundelkhand", has remained backward educationally, infrastructurally and growth in human development. Though the Union government had announced special economic package for the region few years back, however, the fruits of development are still awaited. The area is typically known for recurring droughts and scarcity of water during the last couple of decades, and in dire need of overall development.

\section{Data Used and Methodology}

Survey of India (SOI) Toposheet numbers 54L/6 and 54L/7 on 1:50,000 scale, were obtained from Survey of India, Dehradun, and used for the base map preparation. The toposheets were scanned and georeferenced in Erdas Imagine 14 software with the help of Ground Control points (GCPs) and were projected into Universal Transverse Mercator (UTM) projection, taking World Geodetic System (WGS84) as the datum. The study area lies in UTM zone $44 \mathrm{~N}$. For geo-referencing, the latitudes and longitudes of a reference map were converted into X-Y co-ordinates, and the corresponding X-Y coordinates were transferred on the map. After georeferencing, these toposheets were mosaiced and watershed boundary was delineated from Advanced Space borne Thermal Emission and Reflection Radiometer (ASTER) data of 30 meter resolution, which is freely available and downloaded from http://www.earthexplorer.usgs.gov, using SAGA software, and this data was subsequently utilized for the preparation of Digital Elevation Model (DEM).

IRS-P6 LISS III data, having a spatial resolution of 23.5 meter, (Path/Row: 98/54) of 27th February, 2005 was procured from National Remote Sensing Centre (NRSC), Hyderabad (Figure 2).

The other relevant information was obtained from various government sources in form of maps, reports and ancillary data set.

The drainage network was created manually by digitizing drainage lines and overlaid on DEM in ArcGIS 10 (Figure 3). The drainage network of the basin and the stream ordering and morphometric parameters were computed using standard methods as adopted by Horton and Strahler [24] [25]. Standard visual image interpretation method based on photo-recognition elements such as tone, texture, size, shape, pattern, association and field knowledge was followed. Land use/land cover categories such as agriculture land, dense forest, open forest, open scrub, settlement, stone quarry, exposed rock, waste land and water body, were delineated on the basis of image interpretation, which was supplemented by ground truth verification. Land use/cover map of 2005 was imported to ArcGIS for digitization, editing and topology building. Polygon ids were assigned for each Land use/cover category and area both in $\mathrm{km}^{2}$ as well as in percentage 


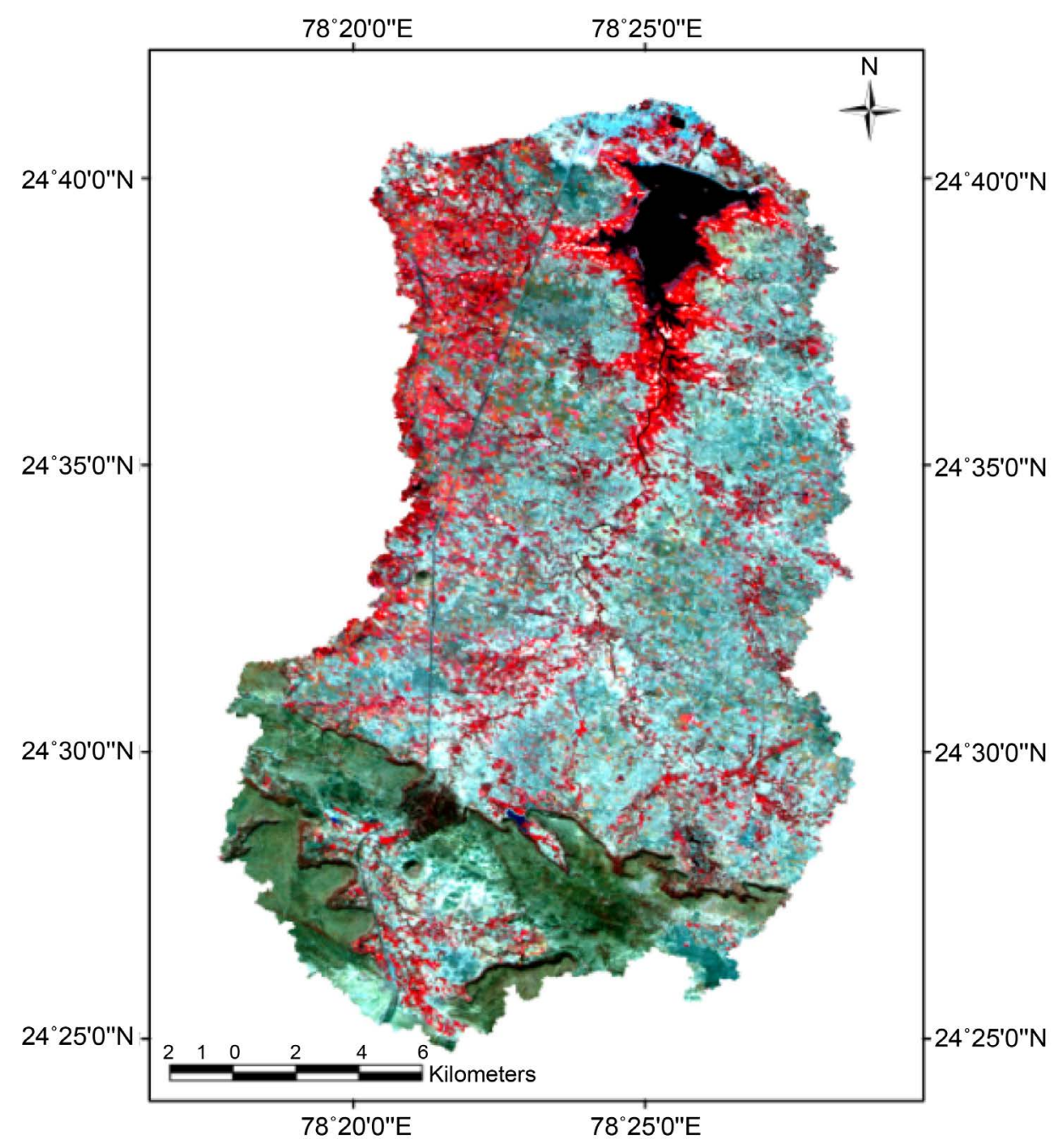

Figure 2. IRS-P6 LISS III standard FCC, 2005.

was computed in GIS.

In order to understand slope characteristics of the watershed, slope map was derived from DEM. Employing the standard procedure for calculating the slope in degrees, three classes as gentle $\left(0^{\circ}-13^{\circ}\right)$, moderate $\left(13^{\circ}-25^{\circ}\right)$, and steep $\left(25^{\circ}-38^{\circ}\right)$ were assigned (Figure 4).

Sediment Yield Index (SYI) was computed taking inputs from drainage parameters, land use/cover and slope of area to assess sediment yield rate, in Govindsagar catchment.

\section{Results and Discussion}

\subsection{Morphometric Analysis}

Morphometric analysis provides quantitative description of basin geometry to understand initial slope or inequalities in the rock hardness, structural controls, recent diastrophism, geological and geomorphic history of a drainage basin [25]. The drainage in a 


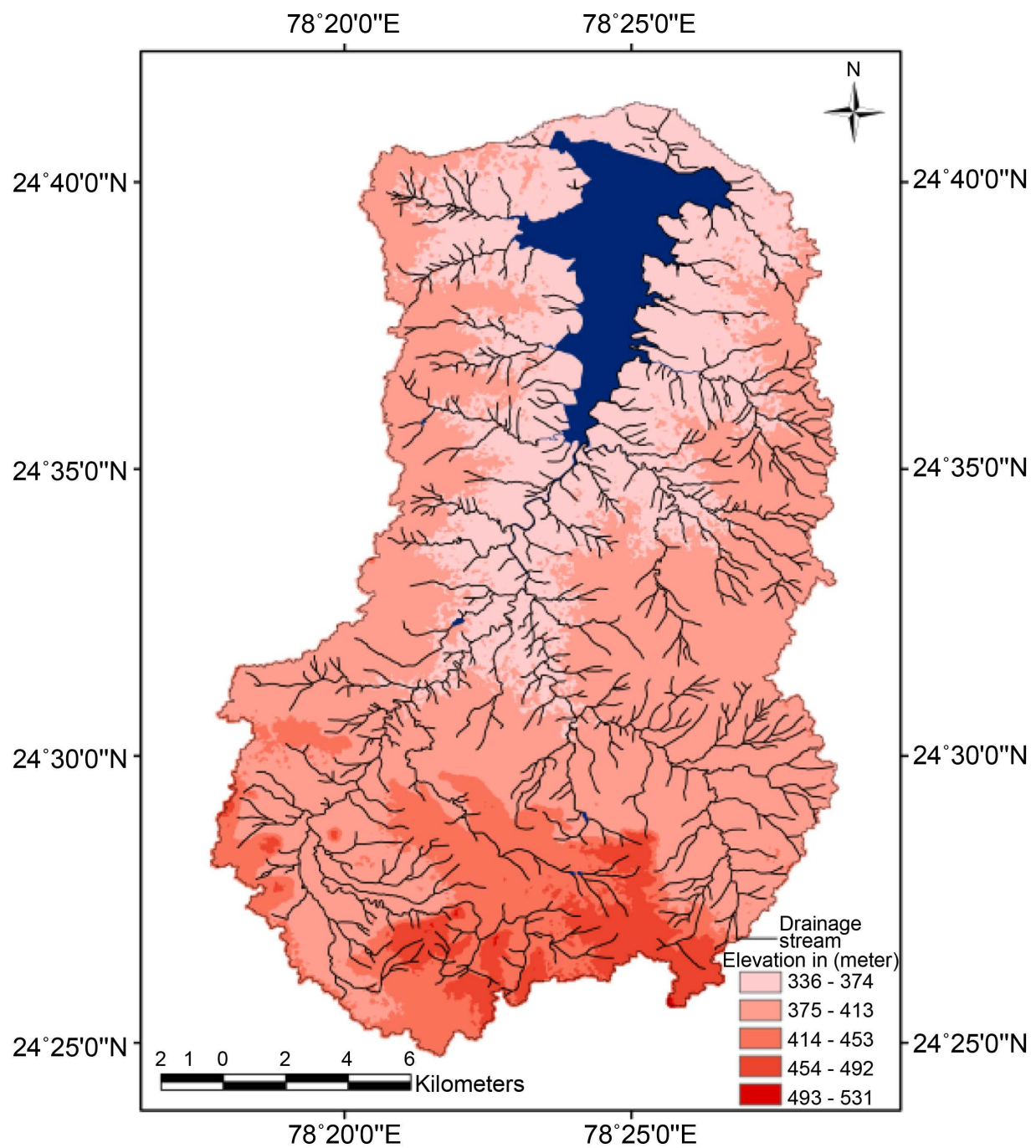

Figure 3. Drainage network superimposed on DEM.

basin is largely governed by the rocks, soil and rock structures, and can be used to draw inferences about lithology, structure and soil types. The higher order streams are often controlled by the rock structures, while the behavior of the lower order streams and their inter-relationships provide information about nature of rocks and soils [26]. The parameters utilized for the assessment of morphometric analyses are categorized into Linear, Areal and Relief aspects. The linear aspects include stream order, stream length, mean stream length, stream length ratio, and bifurcation ratio, while areal aspects include drainage density, steam frequency, drainage texture, basin shape, from factor, circularity ratio and elongation ratio, whereas relief aspects consists of relief ratio. The designation of stream order is based on a hierarchic ranking of streams, and is a useful indicator of stream size, discharge and drainage area [27]. Measurement of these linear, areal and relief parameters envisages to understand basin morphology [28].

Stream ordering is the first step of quantitative analysis of the drainage basin as proposed by Horton [24], and later modified by Strahler [25]. The study area has 720 


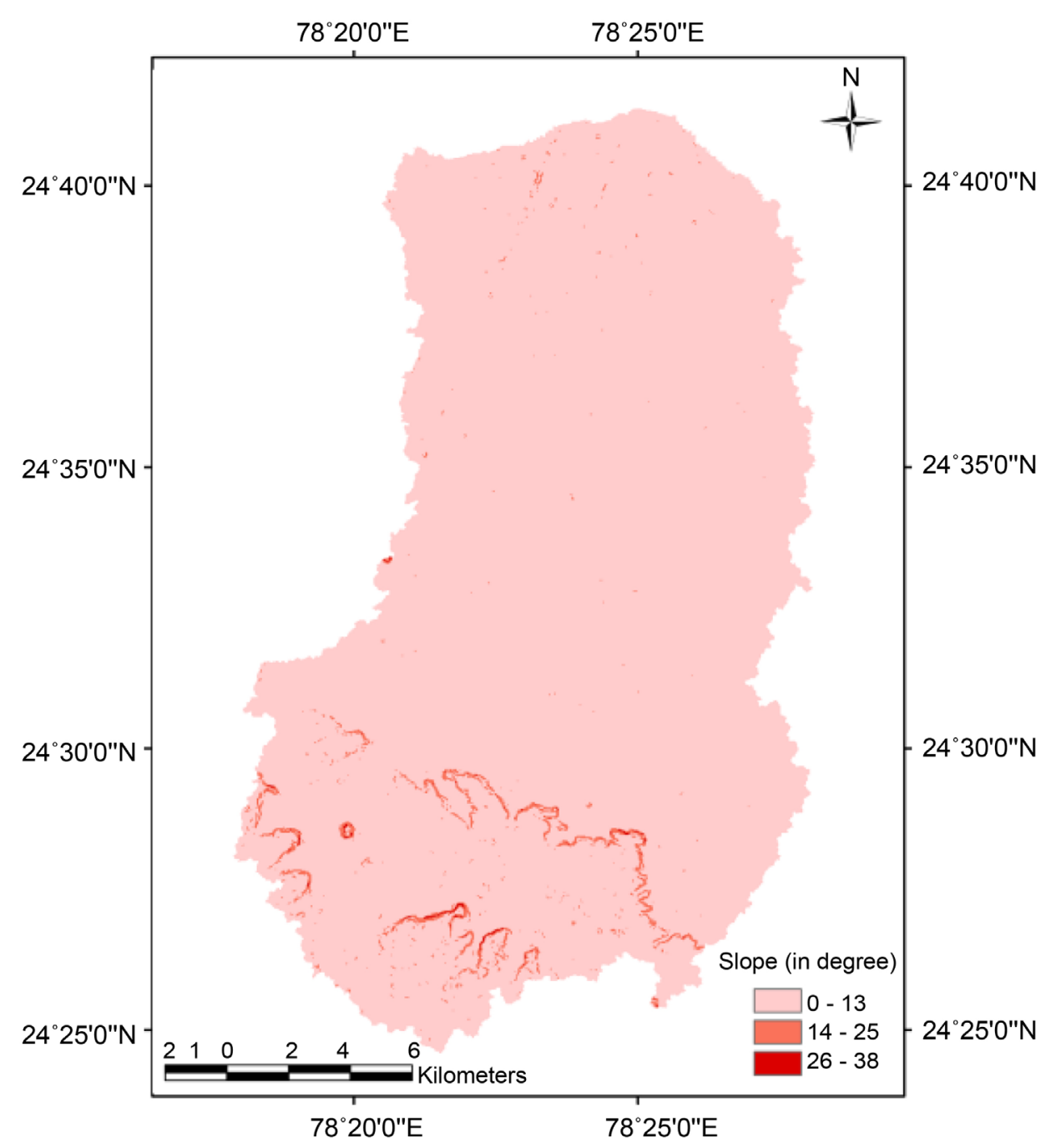

Figure 4. Slope map.

various orders of streams and the main Shahzad river is of the 6th order stream. These streams contribute their discharge to Govingsagar reservoir. The main Shahzad river is of the 6th order (Table 1). The stream length ratio of different order in the Govindsagar catchment area reveals variation in slope and topographic conditions. Accordingly, stream length ratio has an important relationship with the surface flow discharge and erosional stage of the basin [29]. The bifurcation ratio values of Govindsagar catchment area range from 2.00 to 5.23 , which indicate less structural control on the drainage development i.e. the drainage pattern of the study area has not been distorted because of structural disturbances.Drainage density is the total length of streams of all orders divided by the area of drainage basin and indicates closeness of spacing of channels [24]. The catchment has a drainage density of $4.87 \mathrm{Km}^{-1}$ falling in high drainage density category which may be attributed to impermeable subsurface materials. The drainage texture value is 4.53 , which indicates moderate texture. Basin shape is 2.54 , which indicates peaked flood discharge and high stream flow carrying sediment load. Form 
Table 1. Result of the morphometric analysis of Govindsagar catchment.

\begin{tabular}{|c|c|c|c|c|c|c|}
\hline \multicolumn{7}{|c|}{ Linear Aspects } \\
\hline Stream Order $(\mathrm{Nu})$ & 1 st & 2nd & $3 \mathrm{rd}$ & 4 th & 5 th & 6 th \\
\hline No. of Streams & 550 & 136 & 26 & 6 & 2 & 1 \\
\hline Stream Length $(\mathrm{Lu})$ in $\mathrm{Km}$ & 354.16 & 1364.63 & 68.12 & 38.28 & 21.42 & 27.33 \\
\hline Mean Stream Length (Lsm) & 0.64 & 10.03 & 2.62 & 6.38 & 10.71 & - \\
\hline Stream Length Ratio (RL) & 3.85 & 0.05 & 0.56 & 0.56 & 1.27 & - \\
\hline Bifurcation Ratio (Rb) & 4.04 & 5.23 & 4.33 & 3 & 2 & - \\
\hline $\begin{array}{l}\text { Mean Bifurcation Ratio } \\
\text { (Rbm) }\end{array}$ & \multicolumn{6}{|c|}{3.72} \\
\hline \multicolumn{7}{|c|}{ Areal Aspects } \\
\hline Drainage Density (D) $\left(\mathrm{Km}^{-1}\right)$ & \multicolumn{6}{|c|}{4.87} \\
\hline Drainage Texture (Dt) & \multicolumn{6}{|c|}{4.53} \\
\hline Basin Shape (Bs) & \multicolumn{6}{|c|}{2.54} \\
\hline Form Factors (Rf) & \multicolumn{6}{|c|}{0.39} \\
\hline Circularity Ratio (Rc) & \multicolumn{6}{|c|}{0.19} \\
\hline \multicolumn{7}{|c|}{ Relief Aspect } \\
\hline Relief Ratio & \multicolumn{6}{|c|}{2.26} \\
\hline
\end{tabular}

factor value of 0.39 , indicates that watershed is less elongated in shape with flat peak flow for longer duration. Circularity ratio (0.19) suggests catchment area is less circular with low to moderate relief (6.26) [30].

\subsection{Land Use/Cover Analysis}

Land use/cover analysis was carried out using IRS-P6 LISS III FCC data. Visual interpretation of FCC data led to the identification and delineation of various land use/cover categories such as agriculture land, dense forest, open forest, open scrub, settlement, stone quarry, exposed rock, waste land and water body (Figure 5). The area statistics of Land use/cover compited in GIS suggests that the catchment occupies an area of about $192.32 \mathrm{~km}^{2}$ under agriculture land, which is $50.08 \%$ of the total watershed area. Dense forest occupies an area of about $68.45 \mathrm{~km}^{2}$, which is largely confined to the southern periphery of the watershed. The area under open forest is about $15.89 \mathrm{~km}^{2}$, whereas open scruboccupies an area of about $91.21 \mathrm{~km}^{2}$. The other land use/cover categories such as settlement, exposed rock, stone quarry, waste land and water body occupy areas of $2.86 \mathrm{~km}^{2}, 0.42 \mathrm{~km}^{2}, 4.75 \mathrm{~km}^{2}, 0.71 \mathrm{~km}^{2}$ and $7.71 \mathrm{~km}^{2}$ respectively (Table 2).

\subsection{Sediment Yield Index (SYI) Analysis}

A number of sediment yield models, both empirical and conceptual, are in practice to address wide ranging soil and water management problems. Most conservation planning for erosion control, however, uses empirical model(s) to estimate average annual soil loss. However such empirical models require input parameter in terms of spatial 


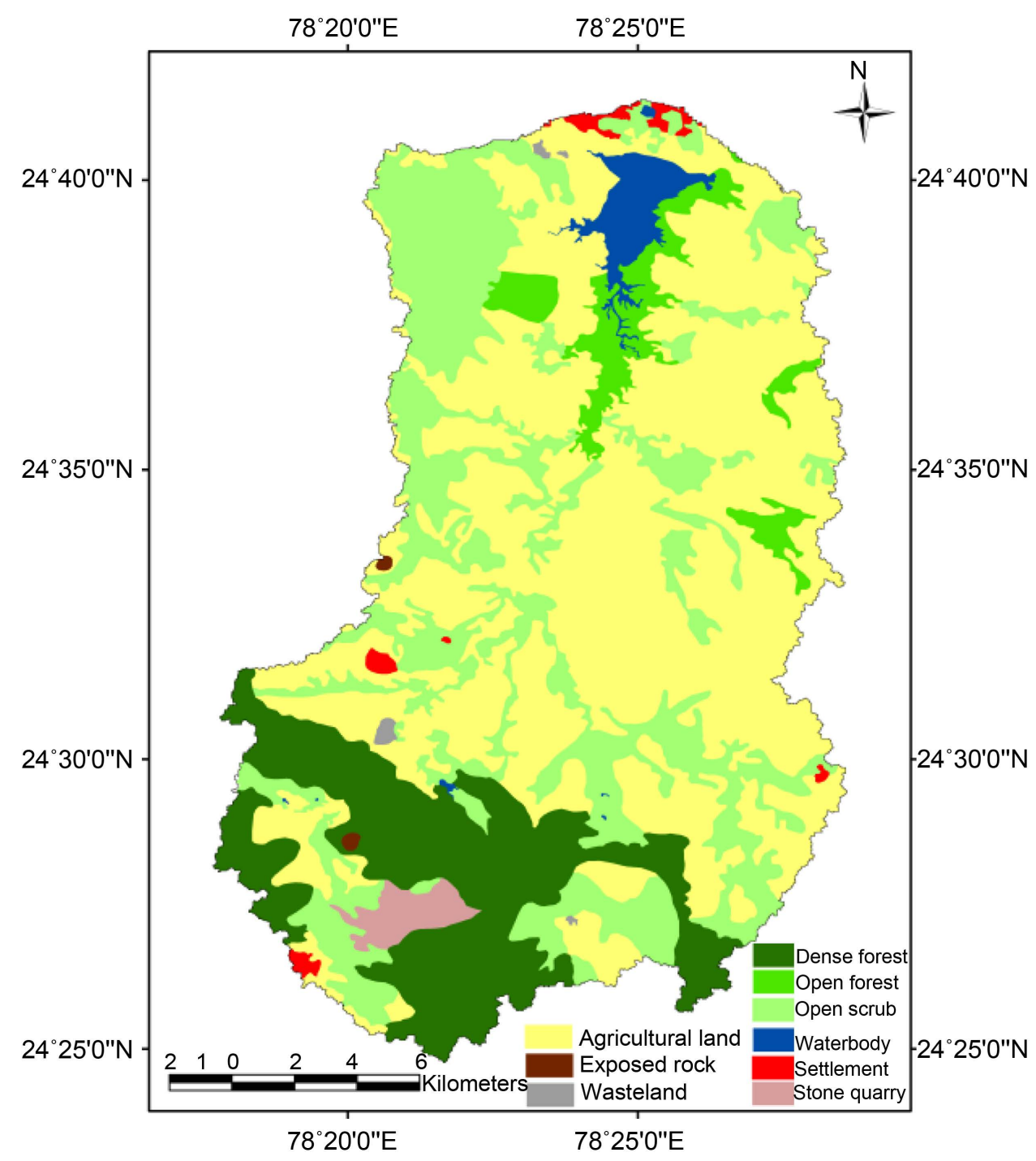

Figure 5. Land use/cover map based on IRS-P6 LISS III.

Table 2. Land use/cover statistics.

\begin{tabular}{ccc}
\hline LU/LC Categories & Area $\left(\mathrm{km}^{2}\right)$ & Area (\%) \\
\hline Agricultural land & 192.32 & 50.08 \\
Dense forest & 68.45 & 17.82 \\
Open forest & 15.89 & 4.13 \\
Open scrub & 91.21 & 23.75 \\
Exposed rock & 0.42 & 0.10 \\
Stone quarry & 4.75 & 1.23 \\
Wasteland & 0.71 & 0.18 \\
Settlement & 2.86 & 0.74 \\
Waterbody & 7.71 & 2.00 \\
Total & 384 & 100
\end{tabular}


information of land use, vegetation cover, soils, slope, drainage density, besides runoff and rainfall intensity. Soil and water conservation over large areas is difficult, expensive and unmanageable, hence requires a selective approach to demarcate smaller hydrological units watershed/sub-watersheds, for more efficient and targeted resource management programs is best suited for conservation planning [22]. The quantitative estimation of Sediment Yield Index (SYI) were carried out by Bali and Karale [17] and updated by National Remote Sensing Agency [31]. A common empirical model for SYI employed under Indian conditions, was carried out following Kumar [32] besides Rao and Mahabaleswara [21], and is as follows:

$$
V_{\mathrm{s}}=1.067 \times 10^{-6} P^{1.384} A^{1.292} D^{0.392} S^{0.129} F^{2.51}
$$

$V_{s}=$ Sediment Yield, $\left(\mathrm{Mm}^{3} /\right.$ year $\left.\times 10^{3}\right)$

$P=$ Annual precipitation, $(\mathrm{cm})$

$A=$ Catchment area, $\left(\mathrm{km}^{2}\right)$

$D=$ Drainage density, $\left(\mathrm{km} / \mathrm{km}^{2}\right)$

$S=$ Average slope of watershed, (degrees)

$F=$ Vegetative cover factor, $\left(\mathrm{km}^{2}\right)$

where, $\mathrm{F}$ can be determined as:

$$
F=0.21 F 1+0.2 F 2+0.6 F 3+0.8 F 4+F 5+F 6+F 7+F 8+F 9 / 9
$$

$F 1=$ Agricultural land

$F 2=$ Dense forest

$F 3=$ Open forest

$F 4=$ Open scrub

$F 5$ = Exposed rock

$F 6=$ Stone query

$F 7=$ Wasteland

$F 8=$ Settlement

$F 9=$ Waterbody

The parameters like $A, D, S$ and $F$ are essential units, which can be derived from stream drainage map, slope map and land use/cover map. However, the parameter $\mathrm{F}$ needs to be redefined on land use/cover information that has been extracted from satellite image. Sediment Yield Index (SYI) of the Govindsagar catchment has been derived using Equations (1) and (2). The value of every parameter in Equations (1) and (2) have been put and the resultant value of $V_{s}$ has come out to be $2.74 \mathrm{M} \cdot \mathrm{m}^{3} /$ year $\times 10^{3}$ (Table 3). The sediment yield rate in Govindsagar reservoir is found to be $0.07 \mathrm{ha} \cdot \mathrm{m} /$ year.

\section{Conclusions}

Soil erosion study and measurements of sediment are quite cumbersome since many factors influence the erosion rates. Precise field observations such as sediment measurement, soil properties, rainfall duration and intensities, vegetation densities and agricultural practices are required. The sediment yield rate of Govindsagar reservoir is found to be $0.07 \mathrm{ha} \cdot \mathrm{m} / \mathrm{year}$ which falls under very low category [33]. Thus, the catchment 
Table 3. Sediment yield and its parameters in Govindsagar reservoir.

$\begin{array}{cc}\text { Area }(\mathrm{A})\left(\mathrm{Km}^{2}\right) & 384.35 \\ \text { Drainage density }(\mathrm{D})\left(\mathrm{Km} / \mathrm{Km}^{2}\right) & 4.87 \\ \text { Slope }(\mathrm{S})(\text { Degree}) & 3.37 \\ \text { Precipitation }(\mathrm{P})(\mathrm{cm}) & 82.27 \\ \text { Vegetative factor }(\mathrm{F})\left(\mathrm{Km}^{2}\right) & 17 \\ \text { Sediment yield }\left(V_{S}\right) \mathrm{M} \cdot \mathrm{m}^{3} / \text { year } \times 10^{3} & 2.74 \\ \text { Sediment yield rate }\left(\mathrm{SY}_{\mathrm{R}}\right)\left(\mathrm{ha} \cdot \mathrm{m} / 100 \mathrm{Km}^{2} / \text { year }\right) & 0.07\end{array}$

is subjected to least soil erosion, and has little effect on water storage capacity. This suggests that the catchment possesses gentle and uniform topography where soil erosion is not a serious threat. Moreover, land use/cover analysis also suggests that the catchment is predominantly agriculture based besides having sufficient forest cover, which restricts the soil erosion.

The result of the study clearly demonstrates that the catchment is less prone to soil erosion but requires regular monitoring from the planners and decision makers for making it better in terms of land and water conservation. Remote sensing data can be employed to derive surface features and can be used as an important input in such studies.

\section{Acknowledgements}

The authors are thankful to the Chairman Department of Geology, A.M.U, Aligarh for extending infrastructure facilities. Senior author wishes to thank Uttar Pradesh Council of Science and Technology, Lucknow for financial support (CST/SERPD/D-1225).

\section{References}

[1] Hudson, N.W. (1995) Soil Conservation. 3rd Edition, Batsford, London, 392.

[2] FAO (1985) Tropical Forestry Action Plan. Committee on Forest Development in the Tropics, FAO, UN, Rome.

[3] FAO (1987) Soil and Water Conservation in Semi-Arid Areas. N. W. Hudson, Soils Bulletin 57, FAO, Rome, 172.

[4] Honore, G. (1999) Our Land, Ourselves-A Guide to Watershed Management in India. Government of India, New Delhi, 238.

[5] Khan, M.A. (1999) Water Balance and Hydrochemistry of Precipitation Components in Forested Ecosystem in the Arid Zone of Rajasthan, India. Hydrological Science Journal, 161.

[6] Tideman, E.M. (1996) Watershed Management, Guidelines for Indian Conditions. Omega Scientific Publishers, New Delhi, 372.

[7] Mabbut, J.A. (1977) Desert Landform. Australian National University Press, Canberra.

[8] Jones, K.R. (1981) Arid Zone Hydrology. FAO, Rome.

[9] Graf, W.L. (1998) Fluvial Process in Dryland Rivers. Springer Verlag, Berlin, 346.

[10] Langbein, W.B. and Schumm, S.A. (1958) Yield of Sediment in Relation to Mean Annual 
Precipitation. Proceedings of the Exeter Symposium, DecTrans. AGU39 1076-1084.

http://dx.doi.org/10.1029/tr039i006p01076

[11] Wilson, L. (1973) Variation in Mean Annual Sediment Yield as a Function of Mean Annual Precipitation. American Journal of Science, 273, 335-349.

http://dx.doi.org/10.2475/ajs.273.4.335

[12] Jansen, J.M.L. and Painter, R.B. (1974) Predicting Sediment Yield from Climate and Topography. Journal of Hydrology, 21, 371-380. http://dx.doi.org/10.1016/S0022-1694(74)80006-5

[13] Jansson, M.B. (1988) A Global Survey of Sediment Yield. Geografiska Annaler, 70A, 81-98. http://dx.doi.org/10.2307/521127

[14] Milliman, J.D. and Syvitski, J.P.M. (1992) Geomorphic/Tectonic Control of Sediment Discharge to the Ocean: The Importance of Small Mountainous Rivers. The Journal of Geology, 100, 525-544. http://dx.doi.org/10.1086/629606

[15] Summerfieid, M.A. and Hulton, N.J. (1994) Natural Controls of Fluvial Denudation Rates in Major World Drainage Basins. Journal of Geophysical Research, 99, 13871-13883.

[16] Narayan, D.V.V. and Babu R. (1983) Estimation of Soil Erosion in India. Journal of Irrigation and Drainage Engineering, 109, 419-431. http://dx.doi.org/10.1061/(ASCE)0733-9437(1983)109:4(419)

[17] Bali, Y.P. and Karale, R.L. (1977) A Sediment Yield Index for Choosing Priority Basins, IAHS-AISH Publishing, Vol. 222, 180.

[18] Goel, M.K. and Jain, S.K. (1998) Reservoir Sedimentation Study of Ukai Dam Using Satellite Data. UM-1/97-98, National Institute of Hydrology, Roorkee.

[19] Katiyar, R., Garg, P.K. and Jain, S.K. (2006) Watershed Prioritization and Reservoir Sedimentation Using Remote Sensing Data. Geocarto International, 21, 55-60. http://dx.doi.org/10.1080/10106040608542393

[20] Kothyari, U.C. and Jain, S.K. (1997) Sediment Yield Estimation Using GIS. Hydrological Sciences Journal, 42, 833-843. http://dx.doi.org/10.1080/02626669709492082

[21] Rao, H.S.S. and Mahabaleswara, H. (1990) Prediction of Rate of Sedimentation of Tungabhadra Reservoir. International Symposium on Water Erosion, Sedimentation, and Resource Conservatio, 1, 12-20.

[22] Khanday, M.Y. and Javed, A. (2011) Sediment Yield Index for Prioritization of Chopan Watershed, Guna District, (M.P.) Using Remote Sensing and GIS Techniques. Geological Processes and Climate Change, 135-150.

[23] Khanday, M.Y. and Javed, A. (2016) Prioritization of Sub-Watershed for Conservation Measure in a Semi Arid Watershed Using Remote Sensing and GIS. Journal of the Geological Society of India, 88, 185-196. http://dx.doi.org/10.1007/s12594-016-0477-7

[24] Horton, R.E. (1945) Erosional Development of Streams and Their Drainage Basins: Hydrophysical Approach to Quantitative Morphology. Geological Society of America Bulletin, 56, 275-370. http://dx.doi.org/10.1130/0016-7606(1945)56[275:EDOSAT]2.0.CO;2

[25] Strahler, A.N. (1964) Quantitative Geomorphology of Drainage Basins and Channel Networks. In: Chow, V.T., Ed., Handbook of Applied hydrology, Mc-Graw Hill Book Company, New York, Section 4-11.

[26] Pandey, N.S. (2001) Principles and Applications of Photogeology. New Age International Limited, India, 1-3.

[27] Strahler, A.N. (1957). Quantitative Analysis of Watershed Geomorphology. Transactions, American Geophysical Union, 38, 913-920. http://dx.doi.org/10.1029/TR038i006p00913 
[28] Biswas, S., Sudhakar, S. and Desai, V.R. (1999) Prioritization of Sub-Watersheds Based on Morphometric Analysis of Drainage Basin, District Midnapore, West Bengal. Journal of the Indian Society of Remote Sensing, 27, 155-166. http://dx.doi.org/10.1007/BF02991569

[29] Sreedevi, P.D., Subrahmanyam, K. and Ahmed, S. (2004) The Significance of Morphometric Analysis for Obtaining Groundwater Potential Zones in a Structurally Controlled Terrain. Environmental Geology, 47, 412-420. http://dx.doi.org/10.1007/s00254-004-1166-1

[30] Reddy, G.P.O., Maji, A.K. and Gajbhiye, K.S. (2004) Drainage Morphometry and Its Influence on Landform Characteristics in a Basaltic Terrain, Central India-A Remote Sensing and GIS Approach. International Journal of Applied Earth Observation and Geoinformation, 6, 1-16. http://dx.doi.org/10.1016/j.jag.2004.06.003

[31] National Remote Sensing Agency (NRSA) (1995) Integrated Mission for Sustainable Development. Guidelines for Field Survey and Mapping, 52.

[32] Kumar, S. (1985) Reservoir Sedimentation. Proceeding of Short Term Course on Planning, Design \& Operation of Reservoirs, Patna University, 1985, 8.

[33] Chakraborti, A.K. (1991) Sediment Yield Prediction \& Prioritisation of Watershed Using Remote Sensing Data. http://a-a-r-s.org/aars/proceeding/ACRS1991/Papers/PS291-2.htm

Submit or recommend next manuscript to SCIRP and we will provide best service for you:

Accepting pre-submission inquiries through Email, Facebook, LinkedIn, Twitter, etc. A wide selection of journals (inclusive of 9 subjects, more than 200 journals)

Providing 24-hour high-quality service

User-friendly online submission system

Fair and swift peer-review system

Efficient typesetting and proofreading procedure

Display of the result of downloads and visits, as well as the number of cited articles

Maximum dissemination of your research work

Submit your manuscript at: http://papersubmission.scirp.org/

Or contact jgis@scirp.org 